\title{
Unshaped Bone Tools from Denisova Cave, Altai
}

\author{
M.B. Kozlikin ${ }^{1}$, W. Rendu' ${ }^{2}$ H. Plisson ${ }^{2}$, M. Baumann ${ }^{2}$ and M.V. Shunkov ${ }^{1}$ \\ 1) Institute of Archaeology and Ethnography, Siberian Branch, Russian Academy of Sciences,Pr. \\ Akademika Lavrentieva 17, Novosibirsk, 630090, RussiaE-mail: kmb777@yandex.ru; \\ shunkov77@gmail.com2Bordeaux University, \\ 2) UMR 5199, PACEA laboratory, Bat. B2, Allée Geoffroy St-Hilaire CS 50023, 33615 Pessac cedex, \\ France E-mail: malvina.baumann@gmail.com; \\ wrendu@u-bordeaux.fr; hugues.plisson@u-bordeaux.fr
}

This study describes a part of the Paleolithic bone industry of Denisova Cave-the site that is key for understanding a complex interaction between various groups of early humans and the Middle to Upper Paleolithic transition. The Initial Upper Paleolithic layers of the cave yielded fossil remains of Denisovans, and the earliest ornaments and bone tools in North and Central Asia. The principal objective of this study is to analyze unshaped bone tools from the Late Middle and Initial Upper Paleolithic from the East Chamber of the cave. Among more than 10 thousand bone fragments, subdivided into three groups in terms of taphonomic, technical, and utilization traces, 51 specimens were selected for study. On the basis of location of use-wear traces that varied according to function, unshaped bone tools such as retouchers, awls, intermediate tools, and knives were revealed for the first time in Denisova Cave. The results of the morphological and use-wear analysis suggest that those tools were used for processing organic materials such as leather, plant fibers, and wood. Unshaped tools indicate a developed industry that preceded, or was contemporaneous with, the formal types of tools polished points and eyed needles.

\section{Keywords: Altai Mountains, Denisova Cave, Initial Upper Paleolithic, Denisovans, bone industry.}

\section{Introduction}

The issue of the Upper Paleolithic culture origins still remains debatable, since the picture of evolutionary development created on the basis of European materials is not considered universal any more. As shown by the results of studies conducted in Africa, Eurasia, and Oceania in recent decades, the model of succession of cultures in the European Paleolithic just summarizes the local scenario of peopling processes. The context of Denisova Cave and other multilayered Paleolithic sites in the northwestern Altai does not agree with the European concept of Paleolithic development. The results of investigation of these sites indicate the concurrent existence of Denisovans, an earlier unknown population of the genus Homo, with Neanderthals in southern Siberia. Besides, they point to a relatively early (about 50-45 ka BP) appearance of stone and bone working technologies, as well as non utilitarian items, which correspond to the behavior of anatomically modern humans, though no evidence of the presence of such humans in 
Altai in the Initial Upper Paleolithic has so far been found. The concept of "modern behavior" itself is based upon analyses of the activities of Homo sapiens sapiens, whose representatives were the founders of the Upper Paleolithic traditions in the territory of Europe. Certain modern behavioral traits were refl ected in earlier materials in the African continent (Henshilwood, Marean, 2003). Before the appearance of anatomically modern humans, some groups of European Neanderthals seem to have experienced innovations, in particular in symbolic fi eld (Hoffmann et al., 2018). The semantic shift between biological and cultural modernity, resulting from the historical background of prehistoric researches, could lead to a circular reasoning when enlarging the focus geographically and chronologically. To avoid such a situation, the context of any site must be analyzed taking into account its specifics, whatever took place in the western part of Eurasia at that time. Archaeological and anthropological materials from Denisova Cave are indicative of the gradual evolutionary development of behavioral traits typical of anatomically modern humans on the basis of local culture (Derevianko, 2010). This process is reflected not only by the stone industry but also by the bone. Denisova Cave is situated in the upstream flow valley of the Anuy River, in the low-mountain and mid-mountain zone of the northwestern Altai, at $690 \mathrm{~m}$ a.s.l. (Fig. 1). The cave consists of several narrow dark chambers, interconnected through the Main Chamber. The cultural and chronological range of Pleistocene deposits at the site is the greatest such range for North and Central Asian sites; it covers a period from the Early Middle Paleolithic (about $300 \mathrm{ka} \mathrm{BP}$ ) to the Final Late Paleolithic (Jacobs et al., 2019). Ornaments and tools made from organic materials have been discovered in deposits aged 50-35 ka BP (layers 11.5-11.1 in the Main Chamber, layers 11.2 and 11.1 in the East Chamber, layer 11 in the South Chamber). Their creation at the early stage of the Upper Paleolithic is evidenced not only by the dates of enclosing sediments, but also by those of pendants made of elk incisors and bone points (Douka et al., 2019). Stones, bones, and animal teeth, mammoth tusks, ostrich eggshells and mollusk shells were used as raw materials for manufacturing ornaments. These were treated using various techniques, such as scraping, grinding, polishing, sawing, and drilling (Derevianko, Shunkov, Volkov, 2008; Shunkov, Fedorchenko, Kozlikin, 2018). Along with ornaments and stone tools belonging to the initial Upper Paleolithic, formal bone tools, mainly eyed needles and awls, were discovered in Denisova Cave. Mitochondrial and nuclear DNA recovered from anthropological remains and cave deposits belongs to Denisovans and Neanderthals (Slon et al., 2017). This fact suggests that the transition to the Upper Paleolithic proceeded here on the basis of local Middle Paleolithic culture, as for example at the Arcy-sur-Cure site in France, judging by the results of analysis of the bone industry and ornaments from the Chatelperronian layer of this cave (D'Errico et al., 2003).

Lithic industries from Denisova Cave and Arcy-sur-Cure reflect the continuity of development: Middle Paleolithic types of tools were used along with new shapes. Meanwhile, traces left by H. s. sapiens at the early stage of the Upper Paleolithic are absent at these sites. The bone artifacts found here are not only a new group of artifacts, but also the evidence of using a new type of raw material that was traditionally considered to be culturally specific to anatomically modern humans (Henshilwood, Marean, 2003). Is there a contradiction? 
Tools made of organic materials have been recorded in the Early and Middle Paleolithic assemblages unrelated to anatomically modern humans (D'Errico, Henshilwood, 2007; Backwell et al.; 2008; Li, Shen, 2010; Mozota, 2012; Soressi et al., 2013; Stout et al., 2014; Julien et al., 2015; Zutovski, Barkai, 2016; Doyon et al., 2018). The Middle Paleolithic bone industries are characterized by small typological variability, the Upper Paleolithic ones by a great variety of shapes and manufacturing techniques (cutting, scraping, grinding, and polishing). If formal bone tools typical of the European Upper Paleolithic are discovered in earlier assemblages, they are considered as a sign of "modernity" (Backwell, d'Errico, 2014).Comparative analysis of bone industries is based on series of items, wherein unshaped tools are usually not taken into account. However, such items are recorded not only in the Middle Paleolithic assemblages, but also in the Upper Paleolithic ones. Solutrean assemblages of the last glacial maximum, state of the art of Paleolithic flint knapping, contain eyed needles that are the most ancient in Europe. At the same time, a considerable part of the bone industry in this culture consists of unshaped tools; among these, pressure tools for manufacturing thin leaf-shaped bifaces. These tools revealed by means of technological and use-wear analysis do not have evident signs of social or symbolic specialization. However, since they performed an important technical function, they should be considered one of the type specimens in the Solutrean industry (Baumann, 2014). Manufacture of blanks for Aurignacian tools was based mainly on percussion (Tartar, 2018). Objects of the Aurignacian portable art and antler spearheads with split bases are known better than informal bone tools of this culture. Informal bone tools have become the subjects of special studies rather recently, for several reasons. First, owing to the absence of standardization in their shaping, it is difficult to identify them by typological criteria; second, bone items are often subject to mechanical and chemical destruction, and so are usually fragmented; third, they are hardly distinguishable from bones that were purposefully splintered by humans to extract bone marrow or were gnawed by carnivores. Thus, even if bone fragments are well preserved, it is often very difficult to distinguish shaping from other causes of anthropic or natural fracturing, in the absence of an appropriate method. Within the framework of this study, noteworthy are needles and awls of the Initial Upper Paleolithic from Denisova Cave. The uniqueness of these tools is determined by their function rather than by shaping technology. Eyed needles and awls are generally associated with sewing clothes, weaving and plaiting, i.e. with the ability of treating hides and plant fibers, which suggested the use of various types of tools. Discovery of a series of items of the same type in a single stratigraphic context can be considered the evidence of production areas at the site and its prolonged occupation. This is the reason why we were expecting more than eyed needles and awls in the bone assemblage of the Initial Upper Paleolithic of Denisova Cave.

\section{Material and methods}

Faunal materials from layers 11.4-11.2 in the East Chamber of the cave were analyzed in the course of this study. In layer 11.2, which was accumulated during the period of the fi rst half of MIS 3, artifacts of the Initial Upper Paleolithic have been found. Layers 11.3 and 11.4, formed during the time corresponding to MIS 4 and 5, yielded Middle 
Paleolithic finds. Bone fragments (over 10,000 spec.) up to $1 \mathrm{~cm}$ long were studied visually, without technical aids, and also using a Nikon SMZ-1 stereoscopic microscope. Photo-recording of materials was performed using a Canon 1000D and 100D SLR cameras, with a Canon EF-S $60 \mathrm{~mm}$ macro lens. The bone fragments were divided into three groups by the types of traces on their surface: taphonomic, technical, and from use. Earlier described materials (Semenov, 1957; Fisher, 1995; Villa, d'Errico, 2001; Maigrot, 2003; Pickering, Egeland, 2006; Baumann, Maury, 2013; Baumann, 2014) and experimental data on manufacturing unshaped and formal bone tools were used as a comparative base. Post-sedimentary organic (microorganisms, animals, plants) and inorganic (weathering, soil subsidence, water courses) modifications, resulting in dissolution, cracking, striations, erosion, disintegration, vermiculation, concretions, were looked for. One of the most destructive factors in Denisova Cave was the activity of carnivores, especially hyenas. There are certain criteria that allow damage on bones left by animals to be distinguished from the traces of human activities (Blumenshine, Selvaggio, 1991; Villa, Bartram, 1996; Villa et al., 2004). The traces associated with activities of hyenas are bites, gnawed out areas, deep scratches, and pitted or glazed surfaces formed during digestion-the most widespread mark of the vital activities of hyenas. Gnawed bone fragments are quite numerous; however, bone surfaces and edges have been little altered, probably because of a fast embedding and low temperature of the sediment, which was also propitious for DNA preservation. Consequently, the distinction between natural and anthropic traces is relatively easy there. The overall condition is good, and some samples with a well-preserved spongiosa would even look fresh, without spattering of oxide deposits on most pieces, particularly manganese. Crushed long tubular bones were most frequently the result of brain marrow extraction. The produced splinters could have been used as blanks for bone tools. However, without systematic refitting it is not possible to establish whether they were resulting from operating sequences included in or distinct from the butchering process. Primary spalls on bones and notches from percussions, are considered as traces of man-induced reduction. Smooth surface, curved or V-shaped outlines, oblique angle of the fracture facets (Villa, Mahieu, 1991) are regarded as evidence of fresh-bone knapping.

\section{Results}

During sorting bone fragments from layers 11.4-11.2 in the East Chamber, 51 unshaped tools were found (see Table; Fig. 2) on the basis of $30 \%$ of faunal materials from this portion of section. The general state of preservation of bone materials from Denisova Cave is good, and spongiosa is in perfect condition. Unshaped tools were manufactured from the long tubular bones of ungulates of large (57\%) and middle (43\%) size. One item made of a vertebra, and two items made of rib fragments, have been found. The bones identifiable to a species belong to bison Bison priscus and red deer Cervus elaphus. Tibias were used as a basis. Humeri, femura, and metatarsi were used more rarely. Unshaped bone tools were divided into three categories in terms of localization of wear traces and manifestations of characteristics that allow the functional purpose of items to be determined. The bones showing wear traces on their cortical surfaces are assigned to the group of tools that, since the end of the 19th century, are classified as retouchers (Daleau, 1883). The items with wear traces at one or both ends are subdivided into two groups. The first group consists of tools with a smoothed end, like 
awls, designed to handle soft materials. The second one includes intermediate tools with axial damage to both ends; these tools had the same operating process, but, judging by the variability of wear traces and the morphology of their ends, were used for different purposes. Obviously, tools with retouch and/or wear traces on their longitudinal edges differed functionally.

Retouchers. Items of this type are the most widespread bone tools of the Stone Age. These are known from the Early Paleolithic (Smith, 2013; Kolfschoten et al., 2015), occur in the greatest number in the Middle Paleolithic industries (Costamagno et al., 2018), and were still used in the Upper Paleolithic (Tartar, 2012b; Guadelli et al., 2013) and Neolithic (Taute, 1965). All retouchers have marks of percussions against sharp edges of stone tools. The function of retouchers was studied for the first time by $\mathrm{H}$. Martin, using materials from La Quina, France (1906). According to him, these items could have been used as hammerstones to apply retouch and as anvils to perform cutting work. Later on, experiments were conducted to study the functions of these tools (Semenov, 1957; Shchelinsky, 1983; Bourguignon, 2001; Rigaud, 2007). Most scholars agree that they were used for shaping lithic edges by percussion. Bone retouchers in layers 11.4-11.2 of Denisova Cave are rare; however, these are the first tools of this type found at the site. Blanks vary from long and narrow to short and large. Their length is 4.7-9.9 cm, width $1.1-3.6$, and thickness $0.4-1.0 \mathrm{~cm}$. Such heterogeneity is probably partly due to the small size of the sample and the diversity of the blanks, but also to the fragmentation of the artifacts: on at least 5 of the 8 samples, the impacted area was cut by a fracture, which occurred when the bone was fresh. In terms of density of percussion marks, the tools are distributed non-uniformly. The impact traces include both separate percussion marks (Fig. 3, b), and dense areas of percussion marks with microflaking (1-4 cm long) on the cortical surfaces of bones (Fig. 3, a). Retouchers are typical not only for layers 11.4-11.2: six such tools have been discovered in underlying Middle Paleolithic layer 12.

Tools with rounded end. The collection contains three small points with marks of smoothing. The lengths of the items are $5.6,3.8$, and $6.3 \mathrm{~cm}$, widths $1.2,2.1$, and $1.0 \mathrm{~cm}$, and thicknesses $0.2,0.3$, and $0.2 \mathrm{~cm}$. Two tools are manufactured from ribs of ungulate animals of middle or large size, and the third from a small splinter of diaphysis. On one rib, an oblique break forming a natural trihedral point without traces of additional treatment is a working edge (Fig. 4 , a-c). Working edges of other items are shaped by fi ne abrupt single- or double-sided retouch, as on lithic borers (Fig. 4, d).These tools correspond to the general definition of awls: "elongated objects made from bone material, partially or completely shaped, dimensions and section of which are variable, with a more or less acute point, sometimes smoothed or rejuvenated" (Camps-Fabrer et al., 1990). Awls are commonly considered as instruments for piercing hides or other soft materials (Maigrot, 2003; Christidou, Legrand-Pineau, 2005). Except sewing needles and projectile points, determined by their smooth surface and specific basal end (an eye or slots for fastening), any other pointed items are usually interpreted as awls, irrespective of their actual functions. Sharp ends of these three items became blunted, most probably as a result of working soft organic materials (see Fig. 4, a, b). Wear traces on two tools similar to lithic micro-borers are very small and correspond to the function of perforating medium-soft organic materials (see Fig. 4, d). Wear traces on the third item are more pronounced; undoubtedly, the tool was used for tailoring clothes, but not as an 
awl. The smooth morphology of the rounding, its distribution and extension, giving a spatula aspect to the active end (Fig. 4, a, b), strongly suggest a tiny hide burnisher, like the ones used for compacting the seam or for leather folding. Unlike the Initial Upper Paleolithic awls found in the cave, these tools were manufactured without scraping and grinding. Similar unshaped tools possibly lie in the Middle to Upper Paleolithic transition layers at the sites of Arcy-sur-Cure (Chatelperronian horizon), Cavallo, Cala, and Castelcivita (Uluzzian layers) in Italy, where numerous awls manufactured by scraping and grinding have been found (D'Errico et al., 2004; D'Errico, Borgia, Ronchitelli, 2012). Unshaped points have also been recorded in the earlier assemblages, such as Mousterian horizons of the Combe-Grenal site in Dordogne (Tartar, Costamagno, 2016), in deposits aged about 80-100 ka BP at the Lingjing site in the Chinese province of Henan (Li, Shen, 2010), and in the Early Paleolithic horizons of the Schöningen site in Lower Saxony (Julien et al., 2015).

Tools with axial damage. These items form the most numerous group of unshaped tools (32 spec.). The majority of them have utilization traces, typical for intermediate tools. One (basal) end of tool was for striking, while the opposite one (apical) was for working. Striking against the basal end resulted in compaction of bone tissue that was sometimes with a crushed flange and, more frequently, by appearance of edge spalls. The bevelled apical end can be compacted and have spalls, while scratches caused by contact with the work material cover its cutting edge and polished areas. The degree of concentration and the types of marks at both ends of the tool depends on the worked material, the hammerstone, and the striking angle (Rigaud, 1984; Provenzano, 1998; Tartar, 2012a). Intermediate tools are well known from numerous Upper Paleolithic finds, whose identification caused no difficulty because of similarity with ethnographic analogs (Lartet, Christy, 1865; Chauvet, 1910).Upper Paleolithic intermediate tools were predominantly made of reindeer antlers. All such fi nds from Denisova Cave are made of bone. The length of intact or nearly intact items is $4.5-16.1 \mathrm{~cm}(9.2$ on the average), width $0.9-4.5 \mathrm{~cm}$ ( 2.0 on the average), and thickness $0.5-1.6 \mathrm{~cm}$ (1.0 on the average). The tools are mostly long and massive (relationship between width and thickness is usually 2:1). In terms of morphology, these items can be divided into two groups. The first group involves tools on relatively large blanks, with a convex or straight cutting edge. Wear traces are small overlapping subparallel detachments (Fig. 5). The second group consists of longer and narrower blanks as compared to the above. Their working edge is thicker and blunted as a result of impact loads (Fig. 6, a, b). The basal part is covered by tangential detachments related probably to the shaping of tools (Fig. 6, c, d).More than a hundred such items were discovered in the Early Aurignacian assemblages (Tartar, 2012a). However, they are not specific to the beginning of the Upper Paleolithic, and they also were mentioned in Late Mousterian sites, such as Gazaria in Basque Country, France (Ibid.), Axlor in Biscay, Spain (Mozota, 2012), Karabi Tamchin in Crimea, Russia (Burke, d'Errico, 2008). As in Denisova Cave, they were manufactured mainly using tibias of large ungulates or straight and thick splinters of diaphyses. Tools made from tibias, which are distinguished by their length, thickness, and tissue density, were the most resistant to impact loads. Several finds from the Early Paleolithic assemblage of Schöningen can also be assigned to the items of this type (Julien et al., 2015). The results of experimental use-wear analysis and comparison with ethnographic materials have suggested several assumptions about the function of the 
intermediate tools, including their use as chisel-like tools and barking instruments. Some use-wear signs and morphology of the working edges of items from Denisova Cave (see Fig. 2, 10, 13, 14) confirm the possibility of such use (Semenov, 1957; Rigaud, 1984; Maigrot, 1997; Camps-Fabrer et al., 1998; Provenzano, 1998). The efficiency of these tools has been proved experimentally. However, the functional range was probably larger. Not all the traces fit with the work of woody material, such as on the tip of the sample shown on Fig. 2, 10, which has been crushed by a repeated contact against a harder material.

Tools with damaged edges. Two intact tools are made of long tubular bones (tibia and humerus), most probably belonging to a bison; six items, different in size and morphology, were fragmented before drying of the bones. They are made from long bones (tibia and humerus) of a large ungulate (bison). The dimensions of two biggest items are $16.1 \times 21.5 \times 1.0$ and $11.1 \times 3.5 \times \times 1.0 \mathrm{~cm}$, respectively. Wear traces (Fig. 7, a) typical of intermediate tools have been revealed at their transverse edges adjoining the side working edges, which suggests multi-functionality of the items. All items show retouch at one longitudinal edge. It occupies $1 / 3$ of the length at intact artifacts. Retouch is double-side, marginal on the dorsal side and covering the marrowy canal or spongiosa on the internal face (Fig. 7, c). Retouch on two items is bifacial. The shape of one item resembles a burin spall (Fig. 7, d) produced possibly by accident during utilization or rejuvenation of the tool. The functional purpose of the retouch is confirmed by some longitudinal removals produced during its use as a knife, and, in one case, by a light rounding of the cutting edge and a luster, probably from plant cutting (Fig. 7, b).Such tools are mentioned rarely. The most known retouched bone items are Acheulean bifaces found in Africa, Europe, and in the Near East (Zutovski, Barkai, 2016). These are fully shaped pieces rather than tools with rejuvenation of one of the edges. Middle Paleolithic tools made of bones with retouched edges are known from materials of such sites as Vaufrey (Vincent, 1993), Combe-Grenal, and La Ferrassie (Tartar, Costamagno, 2016) in France, Axlor (Mozota, 2012) and Bolomor (Blasco et al., 2013) in Spain, and also from the Late Mousterian horizon finds in Fumane Cave in Italy (Romandini, Cristiani, Peresani, 2014). As in Denisova Cave, retouched bone artifacts at the majority of sites were discovered mostly along with smoothed points and intermediate tools.

\section{Discussion}

Unshaped bone tools discovered in layers 11.4-11.2 in the East Chamber of Denisova Cave are small in number; however, these are evidence of a developed industry rather than randomly picked bone splinters remaining after butchering animal carcasses and used to retouch stone tools. According to the morphology of tools, they were used to work different materials, including sewing of clothes from leather; severing or cutting of plants; splitting, barking, or carving of wood. In order to determine functions of each tool, it is necessary to expand the database of experimental studies. The variety of blanks, morphology of working edges, and microwear traces suggests that this toolkit was a part of established manufacturing system. The fact that it was produced only with percussive techniques is not a satisfactory argument for refusing the term "industry", or this term should also be declined for the lithic assemblages until the introduction of stone polishing. Being part of the process of meat production, in contrast to lithic 
procurement, the obtaining of bone material, nevertheless, is not more opportunist than the use of beef tallow by modern industry. Concerning the absence of standardization emphasized by many researchers who reject unshaped bone tools as an industry, it should be noted that the use of elongated bone blanks to manufacture such items is no different from the use of stone blades. The lithic industries of Denisova Cave reflect not only the continuity of development as a whole, but also the establishing of the Upper Paleolithic on the basis of the local Middle Paleolithic. In the materials from lithological layers 11.4-11.2 in the East Chamber of the cave, along with Middle Paleolithic tools, Upper Paleolithic shapes are present. While bone items among the Late Middle Paleolithic tools in layer $\mathbf{1 1 . 4}$ were noteworthy as evidence of the use of a new type of raw material, the eyed needles, pipe-shaped beads, pendants, and other ornaments among unshaped tools of the Initial Upper Paleolithic in layer 11.2 are a part of a developed industry. Bone items are very well preserved, which rules out mechanical impact and the probability of considerable displacement in the thickness of cave deposits. Anthropological materials and paleogenetic data pertaining to these deposits suggest the association of the innovations with the activities of (most probably) Denisovans, though the presence of Neanderthals is also observed in layer 11.4. There are no traces of anatomically modern humans at the initial Upper Paleolithic in Denisova Cave.

\section{Conclusions}

Until recently, it was impossible to record unshaped tools in bone industries owing to the complexity of differentiating items of this type from mass faunal materials. Such items can only be classified as tools by their use-wear traces: spalls, compacted areas, microflaking, smoothness, impressions, etc. A unique preservation of organic materials in Denisova Cave simplifies identification of such traces. The results of analysis of the Middle Paleolithic unshaped tools from the East Chamber allow a conclusion to be drawn that items of the said type were rather archaic. Starting from the Middle Paleolithic, they were made on chipped out bone fragments, but the scraping technique was not used; it gained widespread use during the subsequent Upper Paleolithic epoch. The bone industry under consideration, like the stone one, reflects the continuous process of cultural development and formation of the Upper Paleolithic traditions on the basis of the local Middle Paleolithic. Since there is no evidence for the habitation of anatomically modern humans either in Denisova Cave or in the whole of Altai in the Paleolithic, the obtained results suggest that the manufacture of bone tools and the development of Upper Paleolithic traditions in this territory were connected with the culture of Denisovans.

\section{Acknowledgement}

This study was supported by the Center of French-Russian Studies in Moscow (2015), a postdoctoral fellowship provided by the FYSSEN Foundation (2016), International Associated laboratory ARTEMIR (2015-2018), and the Russian Foundation for Basic Research (Project No. 18-09-40100). 


\section{References}

Backwell L.R., d'Errico F. 2014 Palaeolithic bone tools. In Encyclopedia of global archaeology. New York: Springer, pp. 950-962.

Backwell L.R., d'Errico F., Wadley L. 2008 Middle Stone Age bone tools from Howiesons Poort layers, Sibudu Cave, South Africa. Journal of Archaeological Science, vol. 35: 1566-1580.

Baumann M. 2014 A l'ombre des feuilles de laurier, l'équipement osseux solutréen du Sud-ouest de la France: Apports et limites des collections anciennes: Ph.D. dissertation, Université Paris 1 Panthéon-Sorbonne. Paris.

Baumann M., Maury S. 2013 Ideas no longer written in antler. Journal of Archaeological Science, vol. 40: 601-614.

Blasco R., Rosell J., Cuartero F., Peris J.F., Gopher A., Barkai R. 2013 Using bones to shape stones: MIS 9 bone retouchers at both edges of the Mediterranean Sea. PLoS One, vol. 8 (10): 1-10.

Blumenshine R.J., Selvaggio M.M. 1991 On the marks of marrow bone processing by hammerstones and hyenas; their anatomical patterning and archaeological implications. In Cultural Beginnings: Approaches to Understanding Early Hominid Life-ways in the African Savanna. Bonn: GmbH, pp. 17-32.

Bourguignon L. 2001 Apports de l'expérimentation et de l'analyse techno-morpho fonctionnelle à la reconnaissance de processus d'aménagement de la retouche Quina. In Préhistoire et Approche Expérimentale. Montagnac: Monique Mergoil, pp. 35-66.

Burke A., d'Errico F. 2008 A Middle Palaeolithic bone tool from Crimea (Ukraine). Antiquity, vol. 82: 843-852.

Camps-Fabrer H., Cattelain P., Choï S.-Y., David E., Pascual-Benito J.-L., Provenzano N., Ramseyer D. 1998 Fiches typologiques de l'industrie de l'os préhistorique. Cah. VIII: Biseaux et tranchants. Treignes: Cedarc.

Camps-Fabrer H., Ramseyer D., Stordeur D. 1990 Fiches typologiques de l'industrie de l'os préhistorique. Cah. III: Poinçons, pointes, poignards, aiguilles. Aix-en-Provence: Université de Provence.

Chauvet G. 1910 Os, ivoire et bois de renne ouvrés de la Charente, Hypothèses palethnographiques. Angoulême: E. Constantin.

Christidou R., Legrand-Pineau A. 2005 Hide working and bone tools: Experimentation design and applications. In From Hooves to Horns, from Mollusc to Mammoth. Manufacture and Use of Bone Artefacts from Prehistoric Times to the Present. Tallinn: Tallinn Book Printers, pp. 385-396.

Costamagno S., Bourguignon L., Soulier M.-C., Meignen L., Beauval C., Rendu W., Mussini C., Mann A., Maureille B. 2018 Bone retouchers and site function in the Quina Mousterian: The case of Les Pradelles (Marillac-Le-France, France). In The Origins of Bone Tool Technologies: Retouching the Palaeolithic:

Becoming Human and the Origins of Bone Tool Technology. Mainz: RGZM-Tagungen, pp. 1-31.

Daleau F. 1883 Sur des lésions que présentent certains os de la période paléolithique. In Congrès de I'Association Française pour l'Avancement des Sciences. Rouen: Comptes-Rendus, pp. 600-602.

Derevianko A.P. 2010 Three scenarios of the Middle to Upper Paleolithic transition. Scenario 1: The Middle to Upper Paleolithic transition in Northern Asia. Archaeology, Ethnology and Anthropology of Eurasia, vol. 38 (3): 3-17. 
Derevianko A.P., Shunkov M.V., Volkov P.V. 2008A Paleolithic bracelet from Denisova Cave. Archaeology, Ethnology and Anthropology of Eurasia, vol. 34 (2): 13-25.

D’Errico F., Borgia V., Ronchitelli A. 2012 Uluzzian bone technology and its implications for the origin of behavioral modernity. Quaternary International, vol. 259: 59-71.D'Errico F., Henshilwood C.S. 2007Additional evidence for bone technology in the Southern African Middle Stone Age. Journal of Human Evolution, vol. 52: 142-163.

D’Errico F., Julien M., Liolios D., Baffier D., Vanhaeren M. 2004 Les poinçons en os des couches châtelperroniennes et aurignaciennes de la grotte du Renne (Arcy-sur-Cure, Yonne): Comparaison technologiques, fonctionnelles et décor. In Approches fonctionnelles en Préhistoire: XXV Congrès préhistorique de France, Nanterre, 24-26 novembre. Paris: Société préhistorique française, pp. 46-65.

D’Errico F., Julien M., Liolios D., Vanhaeren M., Baffi er D. 2003 Many awls in our argument. Bone tool manufacture and use in the Châtelperronian and Aurignacian levels of the Grotte du Renne at Arcy-sur-Cure. In The Chronology of the Aurignacian and of the Transitional Technocomplexes. Dating, Stratigraphies, Cultural Implications. Lisbon: Inst. Português de Arqueologia Publ., pp. 247-270.

Douka K., Slon V., Jacobs Z., Ramsey C.B., Shunkov M.V., Derevianko A.P., Mafessoni F., Kozlikin M.B., Li B., Grün R., Comeskey D., Devièse T., Brown S., Viola B., Kinsley L., Buckley M., Meyer M., Roberts R.G., Pääbo S., Kelso J., Higham T. 2019 Age estimates for hominin fossils and the onset of the Upper Palaeolithic at Denisova Cave. Nature, vol. 565 (7741): 640-644.

Doyon L., Li Z., Li H., d'Errico F. 2018 Discovery of circa 115,000-year-old bone retouchers at Lingjing, Henan, China. PLoS One, vol. 13: 1-16.Fisher W.J. 1995Bone surface modifi cations in zooarchaeology. Journal of Archaeological Method and Theory, vol. 2: 7-68.

Guadelli A., Fernandez P., Guadelli J.-L., Miteva V., Sirakov N. 2013 The retouchers from the Gravettian Levels in Kozarnika Cave. In The sound of Bones, 8th Meeting of the ICAZ Worked Bone Research Group, Salzburg 2011. Salzburg: ArchaeoPlus, pp. 155-162.

Henshilwood C.S., Marean C.W. 2003 The origin of modern human behavior: Critique of the models and their test implications. Current Anthropology, vol. 44: 627-651.

Hoffmann D.L., Angelucci D.E., Villaverde V., Zapata J., Zilhão J. 2018 Symbolic use of marine shells and mineral pigments by Iberian Neanderthals 115,000 years ago. Science Advances, vol. 4 (2): 1-6.

Jacobs Z., Li B., Shunkov M.V., Kozlikin M.B., Bolikhovskaya N.S., Agadjanian A.K., Uliyanov V.A., Vasiliev S.K., O'Gorman K., Derevianko A.P., Roberts R.G. 2019 Timing of archaic hominin occupation of Denisova Cave in southern Siberia. Nature, vol. 565 (7741): 594-599.

Julien M.-A., Hardy B., Stahlschmid M.C., Uraban B., Conard N.J. 2015 Characterizing the Lower Paleolithic bone industry from Schöningen 12 II: A multi-proxy study. Journal of Human Evolution, vol. 89: 264-286.

Kolfschoten T.V., Parfi tt S.A., Serangeli J., Bello S.M. 2015 Lower Paleolithic bone tools from the 'Spear Horizon' at Schöningen (Germany). Journal of Human Evolution, vol. 89: 226-263.

Kuhn S.L., Stiner M. 1998 Middle Palaeolithic 'creativity': Reflections on an oxymoron? In Creativity in Human Evolution and Prehistory. New York: Routledge Publ., pp. 143-164.

Lartet É., Christy H. 1865 Reliquiae Aquitanicae: Being contributions to the archaeology and palaeontology of Perigord and the adjoining provinces of Southern France. London: Jones, Ruppert.

Li Z.Y., Shen C. 2010 Use-wear analysis confirms the use of Palaeolithic bone tools by the Lingjing 
Xuchang early human. Chinese Science Bulletin, vol. 55: 2282-2289.Maigrot Y. 1997Tracéologie des outils tranchants en os des Ve et IVe millénaires av. J.-C. en Bassin parisien, Essai méthodologique et application. Bulletin de la Société préhistorique française, vol. 94: 198-216.

Maigrot Y. 2003 Etude technologique et fonctionnelle de l'outillage en matières dures animales, La station 4 de Chalain (Néolithique final, Jura, France): Ph.D. dissertation, Université Paris I Panthéon-Sorbonne. Paris.

Martin H. 1906 Maillets ou enclumes en os provenant de la couche moustérienne de la Quina (Charente). Bulletin de la Société préhistorique française, vol. 3 (4): 155-162.

Mithen S. 1994 From domain specific to generalized intelligence: A cognitive interpretation of the Middle/Upper Paleolithic transition. In In the Ancient Mind: Elements of Cognitive Archaeology. Cambridge: Cambridge Univ. Press, pp. 29-39.

Mozota M.M. 2012 El hueso como materia prima: El utillaje óseo del fi nal del Musteriense en el sector central del norte de la Península Ibérica: Ph.D. dissertation, Universidad de Cantabria. Santander

Pickering T.R., Egeland C.P. 2006 Experimental patterns of hammerstone percussion damage on bones: Implications for inferences of carcass processing by humans. Journal of Archaeological Science, vol. 33: 459-469.

Provenzano N. 1998 Fiche générale des objets à biseau distal. In Fiches typologiques de I'industrie osseuse préhistorique. Cah. VIII: Biseaux et tranchants. Treignes: Cedarc, pp. 5-16.

Rigaud A. 1984 Utilisation du ciseau dans le débitage du bois de Renne à La Garenne-Saint-Marcel (Indre). Gallia Préhistoire, vol. 27: 245-253.

Rigaud A. 2007 Retouchoirs sur éclats diaphysaires ou "affûtoirs" de la Labastide (Hautes-Pyrénées). Archéologie des Pyrénées Occidentales, vol. 26: 193-200.

Romandini M., Cristiani E., Peresani M. 2014A retouched bone shaft from the Late Mousterian at Fumane cave (Italy). Technological, experimental and micro-wear analysis. Comptes Rendus Palevol, vol. 14: 63-72.

Semenov S.A. 1957 Pervobytnaya tekhnika. Moscow, Leningrad: Izd. AN SSSR. (MIA; No. 54). Shchelinsky V.E. 1983K izucheniyu tekhniki, tekhnologii izgotovleniya i funktsiy orudiy mustyerskoy epokhi. In Tekhnologiya proizvodstva $v$ epokhu paleolita. Leningrad: Nauka, pp. 72-133.

Shunkov M.V., Fedorchenko A.Y., Kozlikin M.B. 2018 Personalniye ukrasheniya ranney stadii verkhnego paleolita iz yuzhnoy galerei Denisovoy peshchery. In Problemy arkheologii, etnografii, antropologii Sibiri i sopredelnykh territoriy, vol. XXIV. Novosibirsk: Izd. IAET SO RAN, pp. 198-202.

Slon V., Hopfe C., Weiß C.L., Mafessoni F., de la Rasilla M., Lalueza-Fox C., Rosas A., Soressi M., Knul M.V., Miller R., Stewar J.R., Derevianko A.P., Jacobs Z., Li B., Roberts R.G., Shunkov M.V., de Lumley H., Perrenoud C., Gušić I., Kućan Z., Rudan P., Aximu-Petri A., Essel E., Nagel S., Nickel B., Schmidt A., Prüfer K., Kelso J., Burbano H.A., Pääbo S., Meyer M. 2017 Neanderthal and Denisovan DNA from Pleistocene sediments. Science, vol. 356 (6338): 1-12.

Smith G.M. 2013 Taphonomic resolution and hominin subsistence behavior in the Lower Palaeolithic: Differing data scales and interpretive frameworks at Boxgrove and Swanscombe (UK). Journal of Archaeological Science, vol. 40: 3754-3767.

Soressi M., McPherron S.P., Lenoir M., Dogandžić T., Goldberg P., Jacobs Z., Maigrot Y., Martisius N.C., Miller C.E., Rendu W., Ricahrds M., Skinner M.M., Steeles T.E., Talamo S., Texier J.P. 2013 Neanderthals made the first specialized bone tools in Europe. PNAS, vol. 110: 14186-14190. 
Stout D., Apel J., Commander J., Roberts M. 2014 Late Acheulean technology and cognition at Boxgrove, UK. Journal of Archaeological Science, vol. 41: 576-590.

Tartar E. 2012a The recognition of a new type of bone tools in Early Aurignacian assemblages: Implications for understanding the appearance of osseous technology in Europe. Journal of Archaeological Science, vol. 39: 2348-2360.

Tartar E. 2012b Réflexion autour de la fonction des retouchoirs en os de l'Aurignacien ancient. Bulletin de la Société préhistorique française, vol. 109: 69-83.

Tartar E. 2018 La fracturation du bois de renne à l'Aurignacien, mise en évidence d'une nouvelle modalité d'exploitation. In A coup d'éclats! La fracturation des matières osseuses en préhistoire. Paris: Société Préhistorique Française, pp. 119-138.

Tartar E., Costamagno S. 2016 L'utilisation des matières osseuses au Moustérien. In Néandertal à la loupe. Les Eyzies: Musée National de Préhistoire, pp. 89-97.

Taute W. 1965 Retoucheure aus Knochen, Zahnbein, und Stein vom Mittelpaläolithikum bis zum Neolithikum. Fund-berichte aus Schwaben, vol. 17: 76-102.

Villa P., Bartram L. 1996 Flaked bone from a hyena den. Paléo, vol. 8: 143-159.

Villa P., Castel J.-C., Beauval C., Bourdillat V., Goldberg P. 2004 Human and carnivore sites in the European Middle and Upper Paleolithic: Similarities and differences in bone modification and fragmentation. Revue de Paléobiologie, vol. 23: 705-730.

Villa P., d'Errico F. 2001 Bone and ivory points in the Lower and Middle Paleolithic of Europe. Journal of Human Evolution, vol. 41: 69-112.

Villa P., Mahieu E. 1991 Breakage patterns of human long bones. Journal of Human Evolution, vol. 21: 27-48.Vincent A. 1993 L'outillage osseux au Paléolithique moyen: une nouvelle approche: PhD dissertation, Université Paris X. Paris.

Wadley L. 2001 What is cultural modernity? A general view and a South African perspective from Rose Cottage Cave. Cambridge Archaeological Journal, vol. 11: 201-221.

Zutovski K., Barkai R. 2016 The use of elephant bones for making Acheulian handaxes: A fresh look at old bones. Quaternary International, vol. 406: 227-238. 


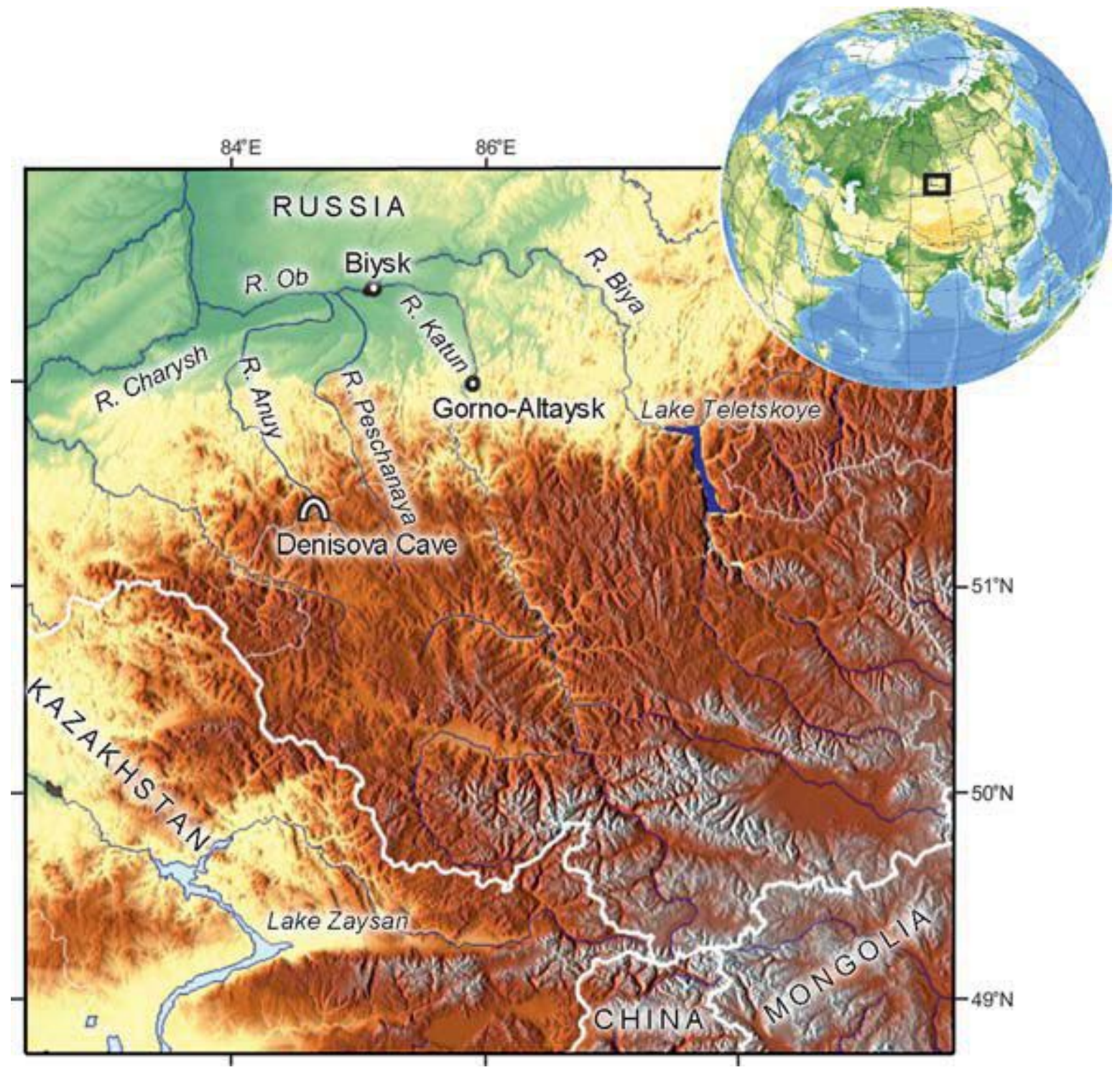

Fig. 1. Denisova Cave on the map of Altai.

\begin{tabular}{|l|c|c|c|c|}
\hline \multirow{2}{*}{ Items } & \multicolumn{3}{|c|}{ Layer } & \multirow{2}{*}{ Total } \\
\cline { 2 - 5 } & 11.4 & 11.3 & 11.2 & 8 \\
\hline Retouchers & 2 & 2 & 4 & 3 \\
Tools with rounded end & 1 & 1 & 1 & 32 \\
Tools with axial damage & 13 & 4 & 15 & 8 \\
Tools with damaged edges & 4 & - & 4 & 51 \\
\hline
\end{tabular}

Unshaped Bone Tools from layers 11.4-11.2 in the East Chamber of Denisova Cave, spec. 

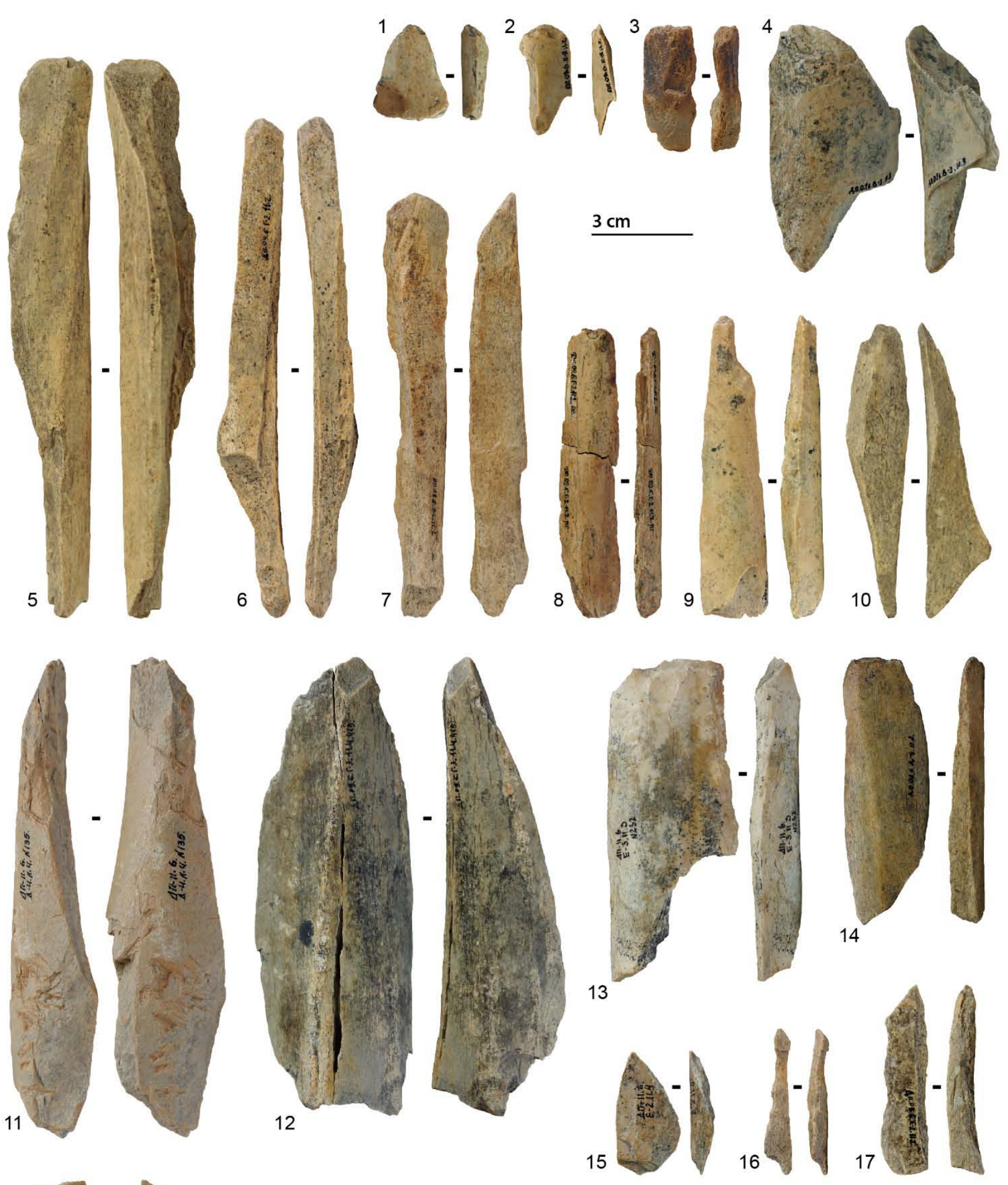

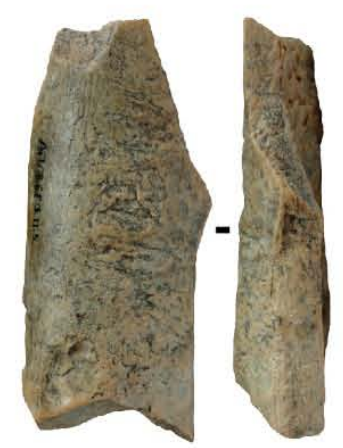

18

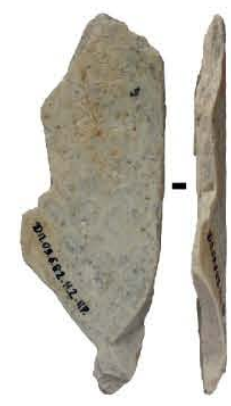

19

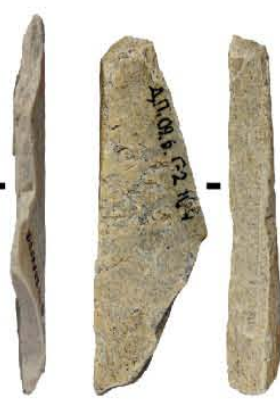

20

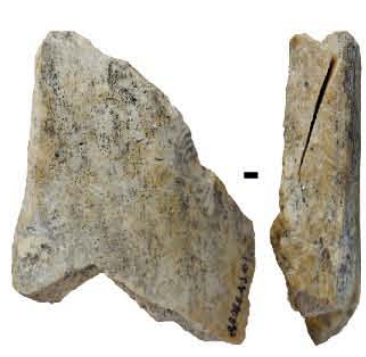

21

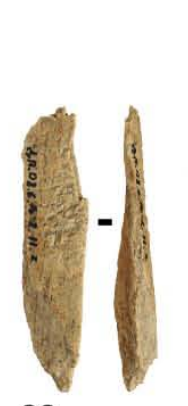

22
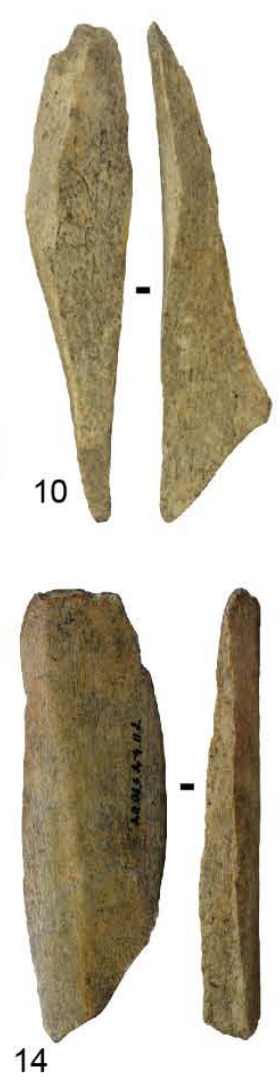

14
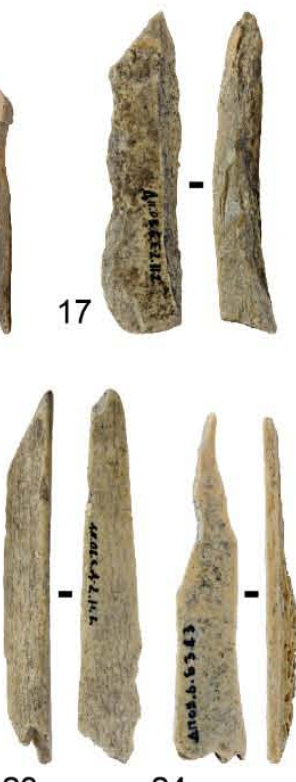

23

Fig. 2. Unshaped bone tools from layers $11.4(1,11,12,15,16,20), 11.3(4,13,18,22,24)$, and $11.2(2,3,5-10,14$, $17,19,22,23$ ) in the East Chamber of Denisova Cave (photos by M. Baumann). 1-14-tools with axial damage; 1517 - tools with damaged edge; 18-22 - retouchers; 23,24 - tools with rounded end. 24 - tools with rounded end. 

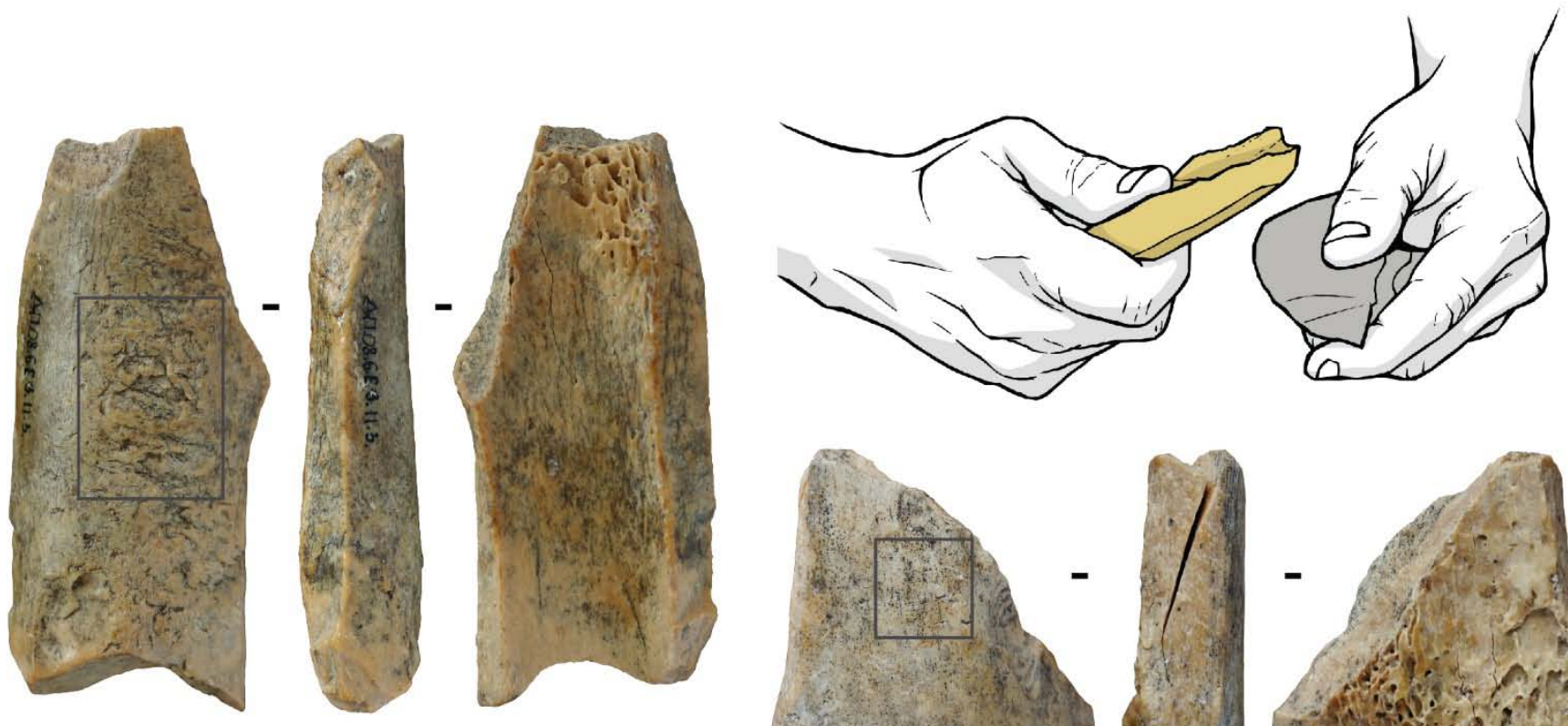

$3 \mathrm{~cm}$
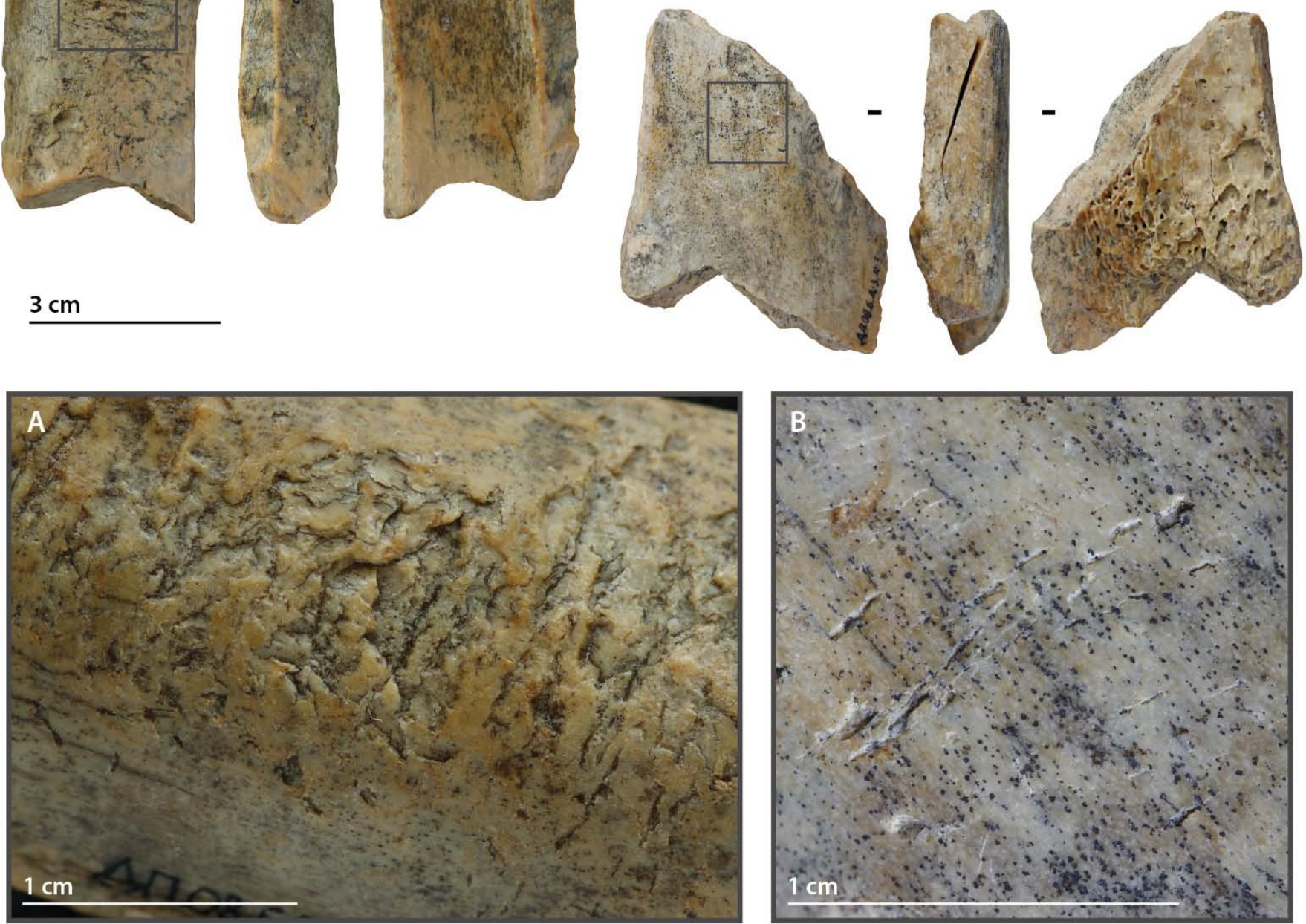

Fig. 3. Bone retouchers with traces of long-term (a) and short-term (b) use from layer 11.3 in the East Chamber of Denisova Cave (photos and drawing by M. Baumann). 

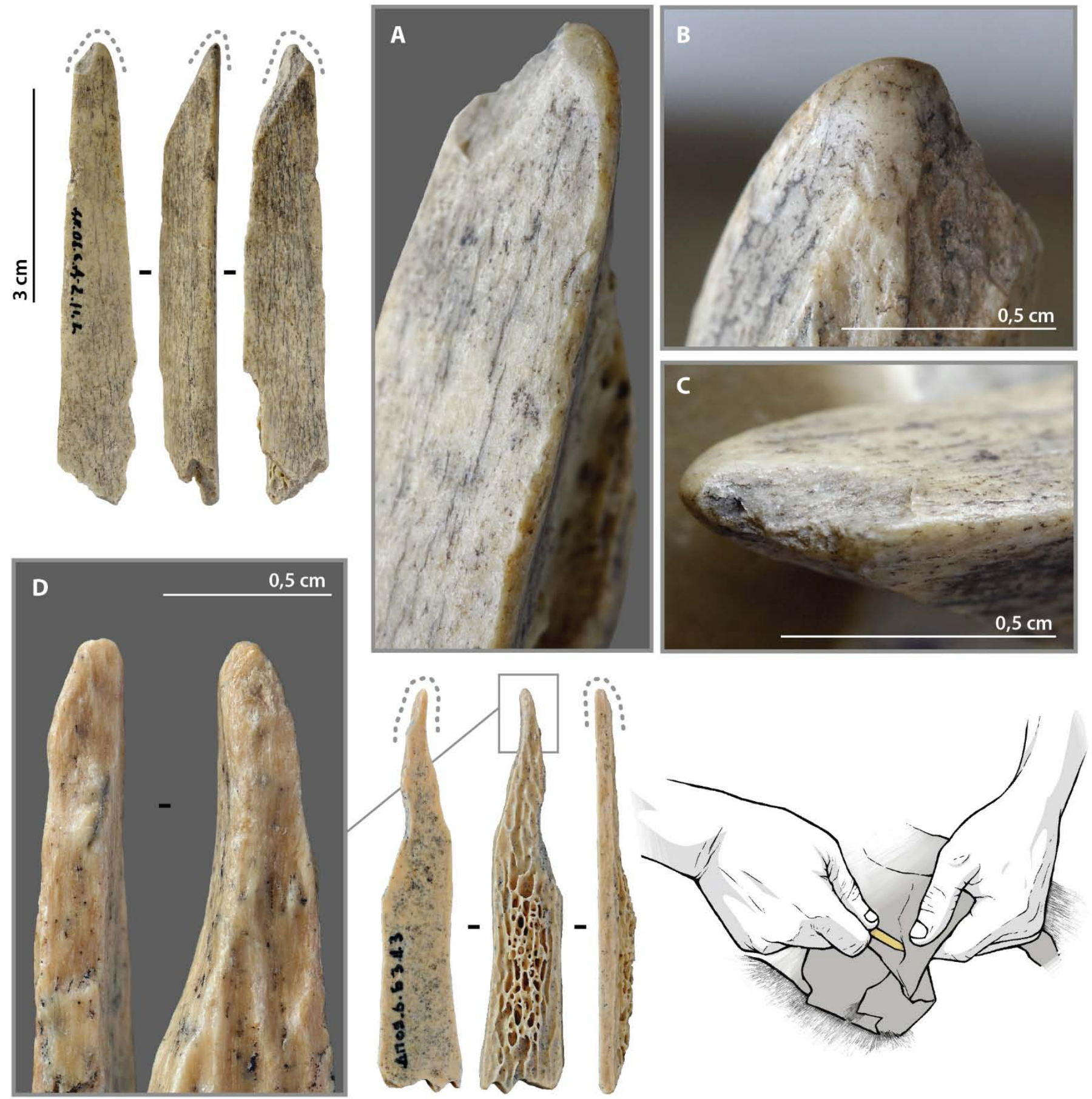

Fig. 4. Tools with rounded end from layers $11.2(\mathrm{a}-\mathrm{c})$ and $11.3(\mathrm{~d})$ in the East Chamber of Denisova Cave (photos and drawing by M. Baumann).

a - smoothed cortical surface and traces of distal end modifi cation; b-smoothed inner surface of the distal end; $c-$ working edge; $d$ - retouched edge. 

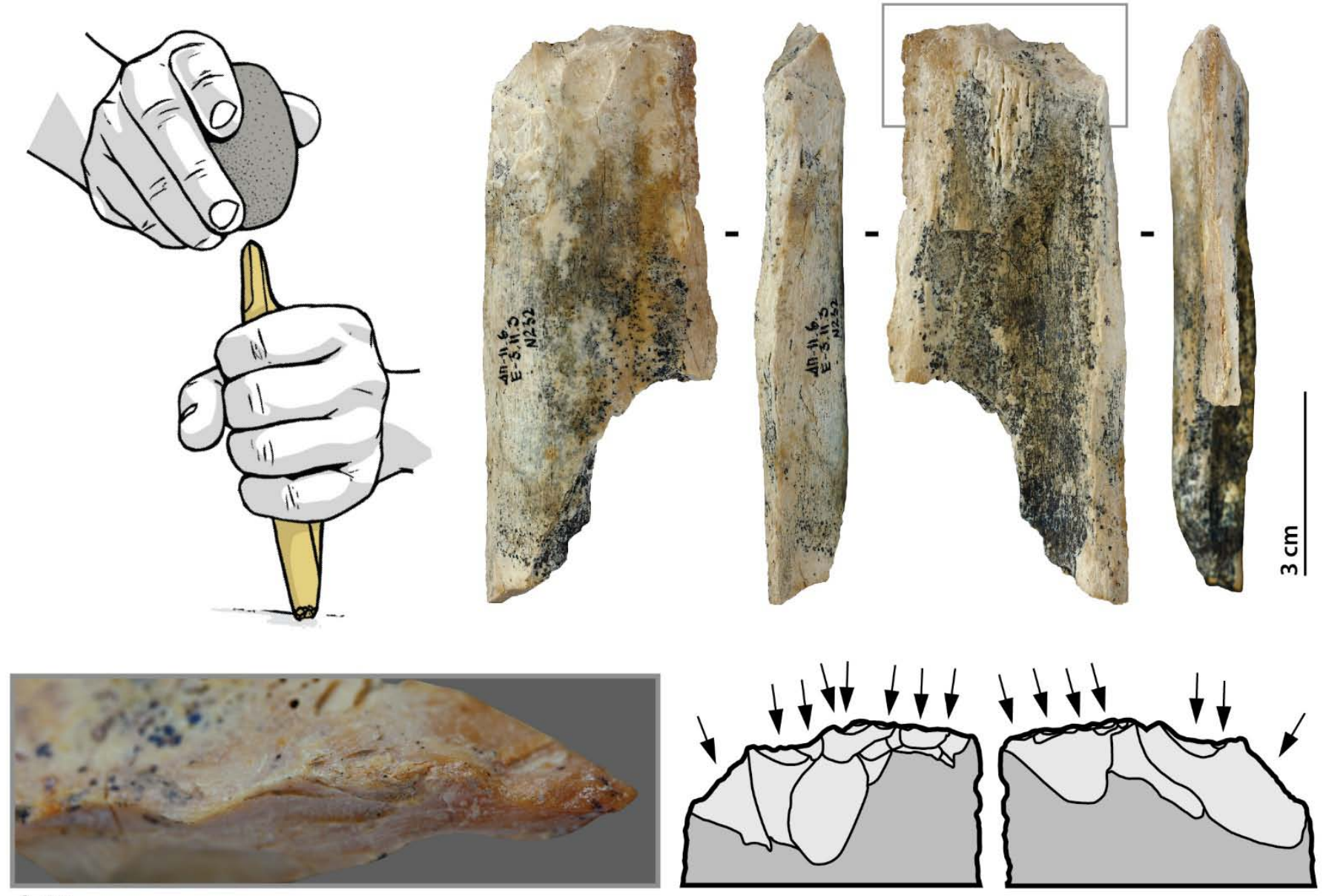

\section{$1 \mathrm{~cm}$}

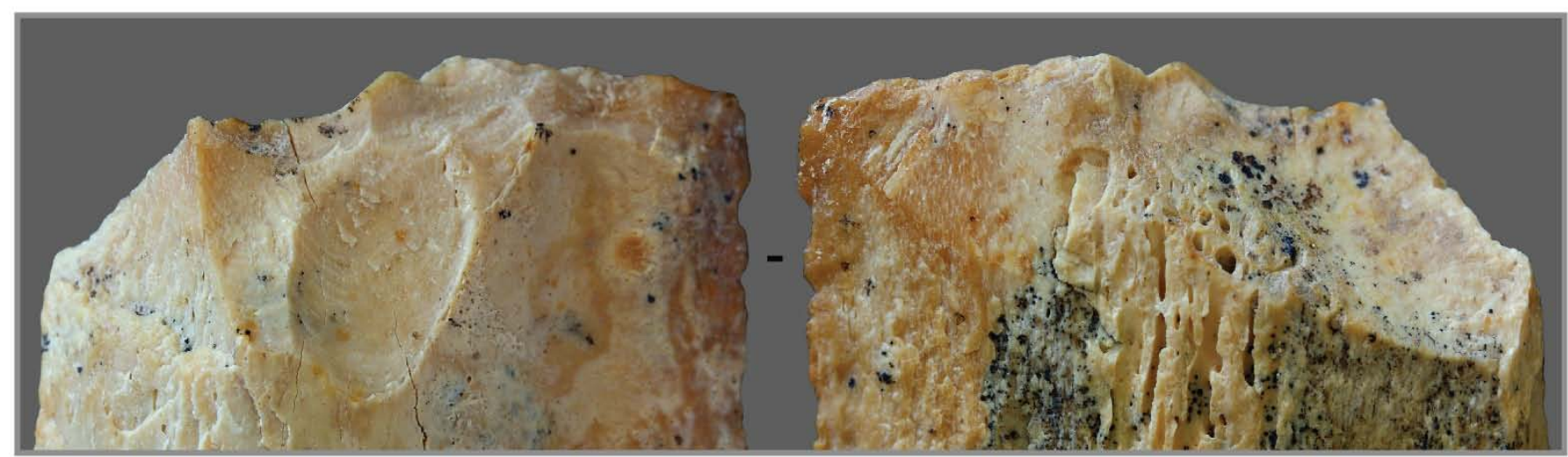

Fig. 5. Intermediate tool from layer 11.3 in the East Chamber of Denisova Cave (photos and drawing by M. Baumann). 

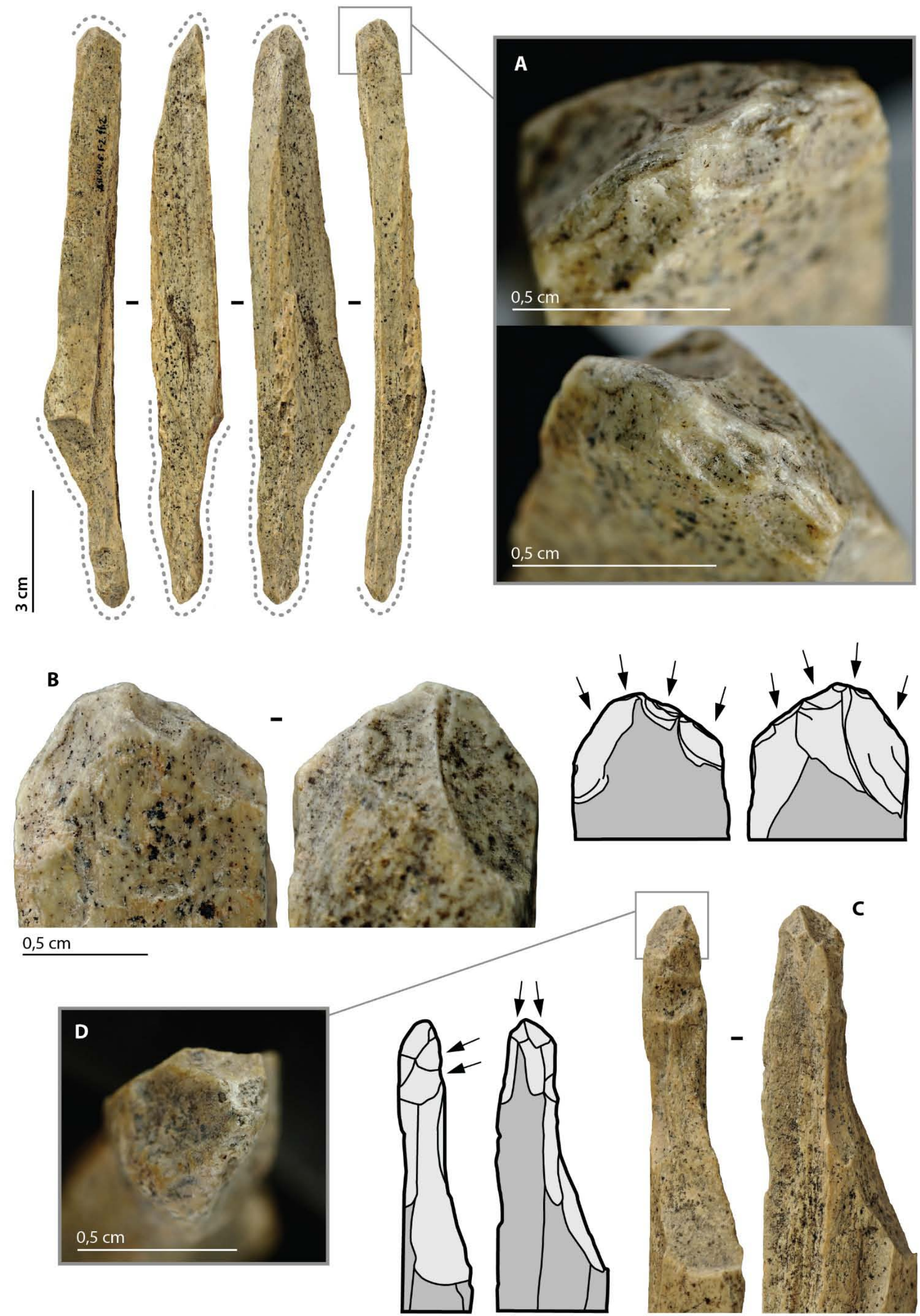

Fig. 6. Intermediate tool from layer 11.2 in the East Chamber of Denisova Cave (photos and drawing by M. Baumann).

$a$ - compaction of the apical end; $b$ - spalls at the apical end; $c$ - compaction of the basal end; $d$ - longitudinal and transverse spalls at the basal end. 

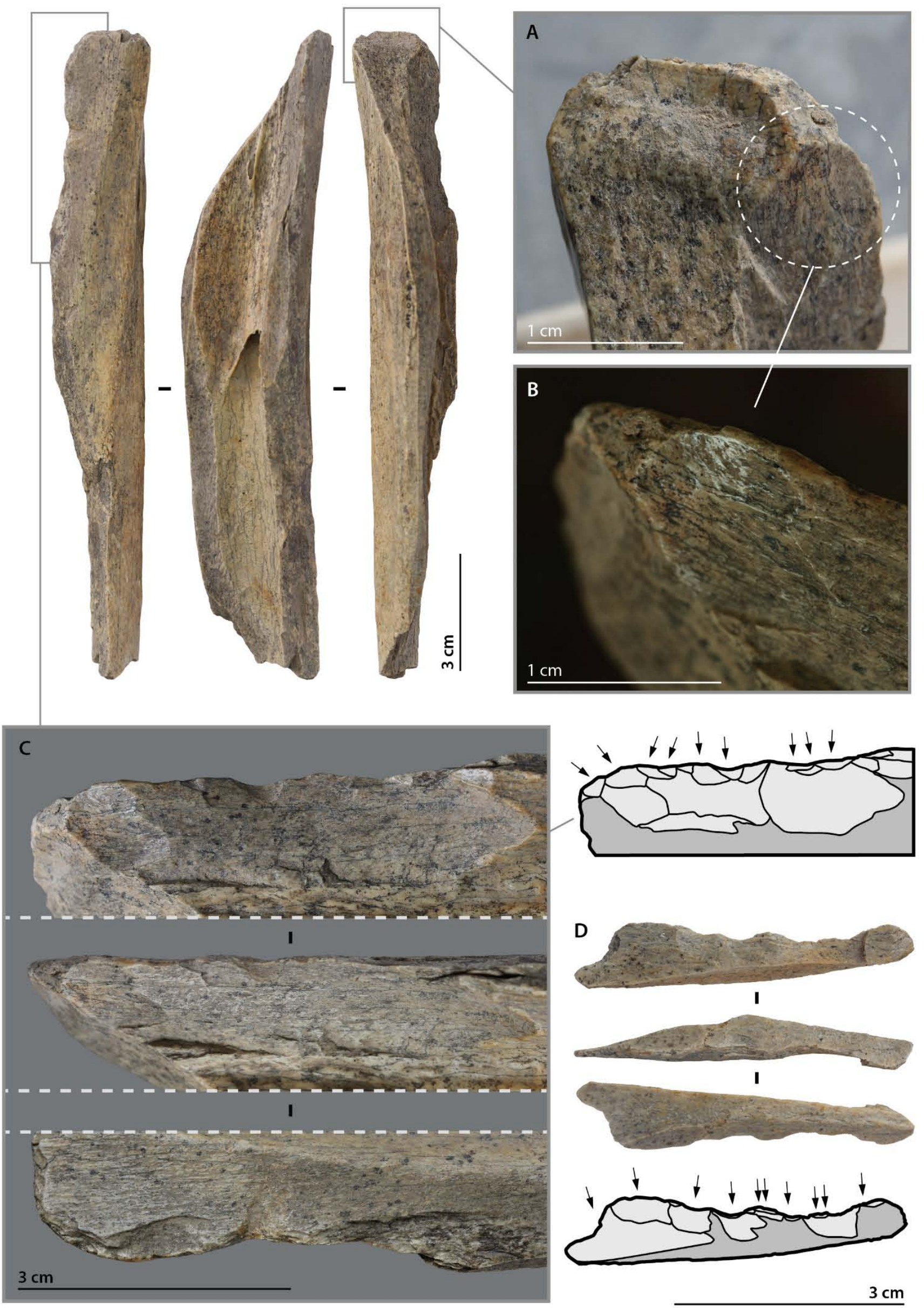

Fig. 7. Tools with damaged edges from layers $11.2(a, b)$ and $11.4(c, d)$ in the East Chamber of Denisova Cave (photos and drawing by M. Baumann).

$a$ - wear traces at the distal end; $b$ - polish of the cutting edge; $c$ - retouched edge; $d$ - burin spall from the retouched edge. 
NB :

The initial manuscript, validated by all the authors, was largely modified without informing the first two signatories before being formatted for publication. To not block the release of the issue in press, the order of the authors has been changed, the first two authors (becoming respectively the 4th and 3rd) acknowledging the raw data but not their interpretation nor their overall perspective.

Le manuscrit initial, validé par tous les auteurs, fut largement modifié à l'insu des 2 premiers signataires avant mise en page pour publication. Afin de ne pas bloquer la sortie du numéro sous presse, l'ordre des auteurs fut modifié, les deux premiers (devenus respectivement les 4ème et 3ème) ne reconnaissant que les données brutes mais pas leur interprétation ni leur mise en perspective.

The version here transcribed is the published version. La version retranscrite ici est la version publiée.

M. Kozlikin, W. Rendu, H. Plisson, M. Baumann, M. Shunkov. Unshaped Bone Tools from Denisova Cave, Altai. Archaeology, Ethnology and Anthropology of Eurasia / Arkheologija, Ehtnografija i Antropologija Evrazii, MAIK Nauka/Interperiodica, 2020, 48 (1), pp.16-28. 110.17746/1563-0110.2020.48.1.016-028) 